\title{
Penerapan Model Problem Base Learning Untuk Meningkatkan Hasil Belajar Ekonomi Materi Siklus Akuntansi Perusahaan Jasa Pada Siswa Kelas XII-IPS SMA Kartika XIV-1 Banda Aceh
}

\author{
Irma Rahayu, SE \\ SMA Kartika XIV-1 Banda Aceh
}

\begin{abstract}
Abstrak
Penerapan Model Problem Base Learning Untuk Meningkatkan Hasil Belajar Ekonomi Materi Siklus Akuntansi Perusahaan Jasa Pada Siswa Kelas XII-IPS SMA Kartika XIV-1 Banda Aceh. Penelitian ini dilakukan di SMA Kartika XIV-1 Banda Aceh selama tiga bulan sejak bulan Agustus sampai Oktober 2020 bertujuan untuk meningkatkan hasil belajar ekonomi materi siklus akuntansi perusahaan jasa dengan menerapkan model problem base learning pada siswa kelas XII-IPS SMA Kartika XIV-1 Banda Aceh. Metode penelitian yang digunakan adalah penelitian tindakan kelas (PTK) yang terdiri atas 2 siklus. Subyek penelitian adalah siswa-siswi Kelas XII-IPS SMA Kartika XIV-1 Banda Aceh tahun pelajaran 2020/2021 sebanyak 23 siswa. Analisis data menggunakan teknik analisis deskriptif komparatif dengan membandingkan kondisi awal dengan hasil-hasil yang dicapai pada setiap siklus, dan analisis deskriptif kualitatif hasil observasi dengan membandingkan hasil observasi dan refleksi pada siklus I dan siklus 2. Dengan menerapkan model problem base learning dalam materi Siklus Akuntansi Perusahaan Jasa bagi siswa kelas XII-IPS pada SMA Kartika XIV-1 Banda Aceh diperoleh hasil tes pada siklus I dengan persentase ketuntasan sebesar 65,2\%, nilai rata-rata kelas sebesar 74,1 dan meningkat pada hasil tes siklus II sebesar 91,3\% dengan nilai rata-rata kelas 82,6. Pada kedua siklus ini terjadi perubahan aktifitas dan perolehan nilai yang signifikan bila dibandingkan dengan pra siklus dengan ketuntasan belajar yang hanya mencapai 43,5\% dan nilai rata-rata adalah 64,6. Dengan demikian melalui penerapan model problem base learning dapat meningkatkan hasil belajar ekonomi materi siklus akuntansi perusahaan jasa pada siswa kelas XII-IPS SMA Kartika XIV-1 Banda Aceh. Selain itu, hasil pengamatan pada proses belajar mengajar memperlihatkan perubahan siswa lebih aktif pada siklus I dan siklus II dibandingkan dengan pra siklus atau sebelum dilakukannya tindakan kelas.
\end{abstract}

Kata Kunci : Hasil Belajar, Model Problem Base Learning, Siklus Akuntansi Perusahaan Jasa

\section{PENDAHULUAN}

Pembelajaran merupakan bagian dari Pendidikan, yang di dalamnya ditunjang oleh berbagai unsur-unsur pembelajaran antara lain tujuan, materi pelajaran, sarana prasarana, situasi atau kondisi belajar, media pembelajaran, lingkungan belajar, metode pembelajaran, serta evaluasi. Kesemua unsur-unsur pembelajaran tersebut sangat mempengaruhi keberhasilan proses belajar mengajar untuk meningkatkan prestasi belajar siswa.

Secara umum ekonomi merupakan pelajaran yang dianggap sulit dan tidak disukai oleh siswa, umumnya siswa tidak menyukai pelajaran ekonomi dan merasa sulit 
untuk mengikutinya, khususnya materi siklus akuntansi perusahaan jasa. Oleh karena itu hasil pembelajaran ekonomi tidak sesuai dengan yang diharapkan.

Kenyataan yang dihadapi saat ini, rata-rata hasil ulangan harian ekonomi nilainya kurang maksimal., dari jumlah siswa kelas XII-IPS SMA Kartika XIV-1 Banda Aceh sebanyak 23 orang, hanya 10 orang siswa atau 43,5\% yang memperoleh ketuntasan belajar. Sedangkan 13 orang atau 56,5\% siswa memperoleh nilai di bawah KKM (Kriteria Ketuntasan Minimal).

Salah satu penyebab kondisi di atas adalah penggunaan strategi pembelajaran yang kurang tepat, yang masih mengenyampingkan aktivitas belajar dan mengabaikan kemampuan memecahkan masalah ekonomi siswa. Oleh karena itu, salah satu langkah yang bisa dilakukan oleh guru sebagai pembimbing peserta didik adalah memilih strategi pembelajaran yang lebih tepat, yang mampu mengembangkan aktivitas dan kemampuan memecahkan masalah ekonomi siswa.

Mengingat pentingnya aktivitas siswa dalam pembelajaran ekonomi sehingga mampu meningkatkan kemampuan memecahkan masalah ekonomi siswa khususnya siklus akuntansi perusahaan jasa, maka diperlukan suatu pendekatan pembelajaran yang mampu mengembangkan aktivitas dan kemampuan memecahkan masalah ekonomi siswa. Salah satu strategi pembelajaran yang saat ini sedang berkembang dan mampu mengembangkan aktivitas dan kemampuan memecahkan masalah ekonomi siswa adalah strategi problem base learning (problem based learning).

Berdasarkan latar belakang di atas maka penulis melakukan suatu penelitian dengan judul "Penerapan Model Problem Base Learning Untuk Meningkatkan Hasil Belajar Ekonomi Materi Siklus Akuntansi Perusahaan Jasa Pada Siswa Kelas XII-IPS SMA Kartika XIV-1 Banda Aceh"

\section{Tujuan Penelitian}

Berdasarkan uraian di atas, maka tujuan penelitian ini adalah untuk meningkatkan hasil belajar ekonomi materi siklus akuntansi perusahaan jasa dengan menerapkan model problem base learning pada siswa kelas XII-IPS SMA Kartika XIV-1 Banda Aceh dan meningkatkan aktivitas belajar ekonomi materi siklus akuntansi perusahaan jasa dengan menerapkan model problem base learning pada siswa kelas XII-IPS SMA Kartika XIV-1 Banda Aceh.

\section{TINJAUAN PUSTAKA \\ Pengertian Hasil Belajar}

Perubahan tingkah laku yang dapat diamati dari penampilan orang yang belajar adalah hasil belajar. Pada hakikatnya hasil belajar menunjukkan tingkat kemampuan siswa dalam mengikuti suatu proses pembelajaran. Tingkat kemampuan siswa dari hasil belajar ini dapat dilihat dari kemampuan kognitif, afektik dan psikomotorik (Sutrisno, 2006). Senada dengan pendapat di atas, Sutrisno (2006) menyatakan bahwa hasil belajar merupakan sesuatu yang diperoleh dari dan sesudah kegiatan pembelajaran berlangsung. Hasil belajar ini dinyatakan dalam bentuk angka, huruf atau kata-kata baik, sedang dan kurang. Hasil belajar ini merupakan kemampuan aktual yang dapat diukur langsung melalui tes yang sesuai dengan tujuan pembelajaran.

\section{Model Problem Base Learning}

Problem base learning adalah salah satu strategi belajar-mengajar yang menekankan aktivitas belajar pada penyelesaian suatu masalah yang diberikan secara 
ilmiah. Ratnaningsih (dalam Trihardiayanti, 2008) mengatakan bahwa : "problem base learning merupakan suatu aktivitas mental siswa untuk memahami suatu konsep pembelajaran melalui situasi dan masalah yang disajikan pada awal pembelajaran". Lebih lanjut Sanjaya (2008:214) menyatakan "Model problem base learning (MPBM) diartikan sebagai rangkaian aktivitas pembelajaran yang menekankan pada proses penyelesaian masalah yang dihadapi secara ilmiah".

Sejalan dengan pengertian yang ada, problem base learning memiliki tiga ciri utama, yaitu (1) merupakan serangkaian aktivitas pembelajaran, (2) Aktivitas pembelajaran diarahkan untuk menyelesaikan masalah dan (3) Pemecahan masalah dilakukan dengan mengunakan pendekatan berfikir secara ilmiah (Sanjaya, 2008:214).

\section{Langkah-langkah Pemecahan Masalah (problem base learning) Ekonomi}

Suatu masalah biasanya memuat situasi yang mendorong seseorang untuk menyelesaikannya namun belum tahu pasti cara menyelesaikan masalah tersebut. Pemecahan masalah dalam ekonomi melibatkan metode dan cara penyelesaian yang tidak standar dan tidak diketahui terlebih dahulu. Oleh karena itu dibutuhkan langkahlangkah pemecahan masalah yang tepat sehingga siswa lebih mudah mengembangkan pengetahuannya untuk mencari penyelesaian masalah.

George Polya merupakan tokoh utama dalam pemecahan masalah. Polya (dalam Tim MKPBM, 2001:91) mengatakan bahwa dalam pemecahan suatu masalah terdapat empat langkah yang harus dilakukan yaitu : (1) memahami masalah, (2) merencanakan pemecahannya, (3) menyelesaikan masalah sesuai rencana langkah kedua, dan (4) memeriksa kembali hasil yan diperoleh (looking back).

\section{Materi Siklus Akuntansi Perusahaan Jasa}

Siklus Akuntansi Perusahaan Jasa membahas empat Kegiatan Pembelajaran, yaitu:

Kegiatan Pembelajaran 1: Tahap Pencatatan

Kegiatan Pembelajaran 2: Tahap Pengikhtisaran

Kegiatan Pembelajaran 3: Kertas Kerja (Worksheet)

Kegiatan Pembelajaran 4: Tahap Pelaporan

\section{METODOLOGI PENELITIAN}

\section{Tempat dan Waktu Penelitian}

Penelitian dilaksanakan di SMA Kartika XIV-1 Banda Aceh di kelas XII-IPS pada materi siklus akuntansi perusahaan jasa. Penelitian dilakukan di kelas XII-IPS karena peneliti adalah guru bidang studi di kelas tersebut. Penelitian ini dilaksanakan selama 3 bulan yaitu pada bulan Agustus s/d Oktober 2020 semester ganjil Tahun Pelajaran 2020/2021. Dilakukan pada waktu tersebut karena materi siklus akuntansi perusahaan jasa merupakan pelajaran yang diajarkan pada semester tersebut.

\section{Subyek Penelitian}

Subyek penelitian adalah siswa-siswi kelas XII-IPS tahun pelajaran 2020/2021. Jumlah siswa sebanyak 23 orang.

\section{Teknik Pengumpulan Data}

Teknik pengumpulan data yang dilakukan dalam penelitian ini yaitu observasi, Dan test. 


\section{Alat Pengumpul Data}

Alat pengumpul data yang digunakan yaitu lembar instrumen aktifitas siswa dalam PBM, lembar instrumen PBM guru, butir soal test .

\section{Analisis Data}

Analisis data yang digunakan adalah analisis deskriptif yang terdiri dari :

Hasil belajar, dengan menggunakan analisis deskriptif komparatif yaitu dengan membandingkan nilai test antar siklus I dengan siklus II dan membandingkan hasil belajar dengan indikator pada siklus I dan siklus II dengan menggunakan rumus sebagai berikut :

$$
\mathrm{PHB}=\frac{\mathrm{P}}{\mathrm{Q}} \times 100 \%
$$

$$
\begin{aligned}
\text { Keterangan: } & \text { PHB } \\
\text { P } & =\text { Penilaian Hasil Belajar } \\
\text { Q } & =\text { Skor yang diperoleh miswa }
\end{aligned}
$$

Analisis deskriptif kualitatif hasil observasi dengan cara membandingkan hasil observasi dan refleksi pada siklus I dan siklus II.

a. Data aktivitas siswa menggunakan kriteria tingkat keaktifan siswa selama pembelajaran menurut Aqib (2009:269) adalah:

Tabel Kriteria Aktivitas Siswa

\begin{tabular}{|c|c|c|}
\hline No & Skor & Kategori Penilaian \\
\hline 1 & 1 & Sangat kurang \\
\hline 2 & 2 & Kurang \\
\hline 3 & 3 & Cukup \\
\hline 4 & 4 & Baik \\
\hline 5 & 5 & Sangat baik \\
\hline
\end{tabular}

Analisis data aktivitas siswa dianalis dengan menggunakan persentase, dengan menggunakan rumus:

$$
\mathrm{P}=\frac{\mathrm{F}}{\mathrm{N}} \times 100 \%(\text { Sudijono, } 2005: 43)
$$

Keterangan:

$\mathrm{P}=$ Persentase yang di cari

$\mathrm{F}=$ Frekuensi aktivitas siswa

$\mathrm{N}=$ Jumlah aktivitas siswa

b. Data aktivitas guru

Data aktivitas guru menggunakan kriteria tingkat keaktifan guru selama pembelajaran menurut Aqib (2009:270) adalah:

\section{Tabel Kriteria Aktivitas Guru}

\begin{tabular}{|c|c|c|}
\hline No & Skor & Kategori Penilaian \\
\hline 1 & 1 & Sangat kurang \\
\hline 2 & 2 & Kurang \\
\hline 3 & 3 & Cukup \\
\hline 4 & 4 & Baik \\
\hline 5 & 5 & Sangat baik \\
\hline
\end{tabular}

Analisis data aktivitas guru dianalis dengan menggunakan persentase, dengan menggunakan rumus: 


$$
\mathrm{P}=\frac{\mathrm{F}}{\mathrm{N}} \times 100 \% \text { (Sudijono, 2005:43) }
$$

Keterangan:

$\mathrm{P}=$ Persentase yang di cari

$\mathrm{F}=$ Frekuensi aktivitas guru

$\mathrm{N}=$ Jumlah aktivitas guru

\section{Prosedur Penelitian}

Penelitian ini dilakukan dengan menggunakan metode Penelitian Tindakan Kelas (PTK) yang terdiri dari 2 siklus. Pada siklus pertama terdiri dari 2 kali tatap muka dan siklus kedua terdiri dari 2 kali tatap muka. Alokasi waktu untuk setiap tatap muka adalah 2 jam pelajaran.

\section{HASIL PENELITIAN DAN PEMBAHASAN Deskripsi Kondisi Awal}

Deskripsi awal pembelajaran atau sebelum dilakukannya tindakan, suasana pembelajaran terlihat berbeda. Pada pra siklus, suasana pembelajaran terlihat kaku, monoton dan kurang dinamis. Peran siswa sangat kecil dalam proses pembelajaran yaitu hanya di saat penulis memberikan tugas untuk dikerjakan. Peran penulis terlihat lebih dominan dalam memberikan penjelasan dan berbagai informasi kepada siswa mengenai materi yang di ajarkan. Berdasarkan hasil pengamatan nilai belajar pada pra siklus maka dapat dianalisa sebagai berikut :

1. Nilai rata-rata kelas sebesar 64,6 dengan pencapaian ketuntasan 10 orang siswa atau 43,5\% siswa yang mempunyai nilai di atas KKM (Kriteria Ketuntasan Minimal). Sedangkan 13 orang atau 56,5\% siswa memperoleh nilai di bawah KKM (Kriteria Ketuntasan Minimal). Adapun KKM ekonomi yaitu 75.

2. Pada pra siklus belum ada siswa yang mendapat nilai yang sangat memuaskan.

3. Secara klasikal siswa belum mencapai ketuntasan belajar.

\section{Deskripsi Hasil Siklus I}

\section{Perencanaan}

a. Menyusun Rencana Pelaksanaan Pembelajaran

Materi yang dipilih dalam penelitian ini adalah penjumlahan dan pengurangan. Berdasarkan materi yang dipilih tersebut, kemudian disusun ke dalam rencana pelaksanaan pembelajaran (RPP). Masing-masing RPP diberikan alokasi waktu sebanyak 2 x 45 menit, artinya setiap RPP disampaikan dalam 1 kali tatap muka. Pada siklus I terjadi dua kali pertemuan atau dua kali tatap muka.

b. Penyiapan skenario pembelajaran

1) Mempersiapkan beberapa hal yang diperlukan dalam pelaksanaan penelitian yaitu: membuat RPP, menyusun instrumen PBM guru peneliti dan menyusun instrumen respon siswa terhadap kegiatan pembelajaran.

2) Mempersiapkan kelompok belajar siswa dengan memperhatikan heterogenitas, kemampuan dan jenis kelamin.

\section{Pelaksanaan}

Pelaksanaan pembelajaran pada siklus I dilaksanakan sesuai perencanaan yang telah disiapkan. Kegiatan pada tahap ini adalah sebagai berikut :

a. Kegiatan belajar mengajar dilaksanakan pada hari selasa tanggal 1 September 2020 dan hari sabtu tanggal 5 September 2020. 
b. Secara klasikal menjelaskan strategi dalam menggunakan model problem base learning.

c. Melaksanakan proses pembelajaran dengan pembelajaran model problem base learning.

d. Siswa dibagi ke dalam 6 (enam) kelompok. Guru memberikan permasalahan tentang siklus akuntansi perusahaan jasa yang berbeda kepada masing-masing kelompok.

e. Kelompok I, dan II ditugaskan untuk melakukan kajian tentang Penggolongan Perusahaan dan karakteristik perusahaan jasa melalui buku-buku yang tersedia termasuk ke perpustakaan.

f. Kelompok III, dan IV ditugaskan untuk melakukan kajian tentang bukti-bukti transaksi melalui buku-buku yang tersedia termasuk ke perpustakaan.

g. Kelompok V dan VI ditugaskan untuk melakukan kajian tentang mekanisme debit kredit tiap akun melalui buku-buku yang tersedia termasuk ke perpustakaan.

h. Setiap kelompok harus membuat laporan sesuai dengan masalah yang dikaji. Hasil kajian itu sebaiknya didukung dengangambar-gambar yang relevan

i. Kelompok II dan IV ditunjuk oleh guru untuk mempresentasikan kajiannya kemudian kelompok I, III, V dan VI yang tidak presentasi dapat mengajukan pertanyaan.

j. Guru meminta siswa untuk menuliskan hasil diskusi pada lembar kertas kerja.

k. Selama siswa bekerja di dalam kelompok, guru memperhatikan dan mendorong semua siswa untuk terlibat diskusi, dan mengarahkan bila ada kelompok yang melenceng jauh pekerjaannya.

1. Guru menutup pembelajaran ini dengan memberikan ringkasan tentang makna materi pelajaran dalam pertemuan ini dan kemudian mengajak berdoa semoga pembelajaran hari ini bermanfaat untuk kita semua

m. Pengamatan terhadap proses kegiatan ini dicatat secara cermat dan didokumentasikan sebagai bagian dari kegiatan pengamatan.

n. Akhir dari kegiatan PBM dilakukan tes tertulis.

o. Penilaian hasil tes tertulis

3. Observasi

Observasi yang dilakukan pada siklus I ini antara lain adalah aktivitas siswa saat PBM berlangsung dan aktivitas pelaksanaan PBM yang diselenggarakan oleh guru.

a. Aktivitas Siswa

Aktivitas siswa siklus I pada pertemuan pertama dan kedua dapat digambarkan dalam tabel berikut ini.

Tabel Aktivitas Siswa Siklus I

\begin{tabular}{|c|l|c|c|}
\hline \multirow{2}{*}{ No } & \multicolumn{1}{|c|}{ Aspek Pengamatan } & \multicolumn{2}{c|}{ Skor Pengamatan } \\
\cline { 3 - 4 } & \multicolumn{1}{|c|}{ Pert. I } & Pert. II \\
\hline 1. & Memperhatikan penjelasan guru & 2 & 2 \\
\hline 2. & Keaktifan dalam bertanya tentang materi & 1 & 2 \\
\hline 3. & $\begin{array}{l}\text { Siswa dapat mengkondisikan dirinya dalam } \\
\text { kelompok yang telah dibentuk }\end{array}$ & 2 & 1 \\
\hline 4. & $\begin{array}{l}\text { Antusias siswa dalam mengikuti kegiatan belajar } \\
\text { mengajar }\end{array}$ & 1 & 2 \\
\hline 5. & Keberanian untuk bertanya pada teman & 2 & 3 \\
\hline & & & \\
\hline
\end{tabular}




\begin{tabular}{|c|l|c|c|}
\hline 6. & $\begin{array}{l}\text { Kemauan untuk saling membantu/bekerjasama } \\
\text { dalam kelompok }\end{array}$ & 1 & 1 \\
\hline 7. & Partisipasi setiap siswa dalam diskusi kelompok & 2 & 2 \\
\hline 8. & $\begin{array}{l}\text { Kemauan mempresentasikan hasil diskusi } \\
\text { kelompok }\end{array}$ & 1 & 1 \\
\hline 9. & $\begin{array}{l}\text { Kemauan memberikan tanggapan, bertanya atau } \\
\text { menyanggah yang dipresentasikan }\end{array}$ & 1 & 2 \\
\hline 10 & Menyimpulkan hasil diskusi & 2 & 2 \\
\hline 11. & $\begin{array}{l}\text { Respon terhadap penghargaan yang diberikan guru } \\
\text { kepada kelompok }\end{array}$ & 2 & 3 \\
\hline \multicolumn{2}{r|}{ Rata-rata } & $\mathbf{1 , 5 5}$ & $\mathbf{1 , 9 0}$ \\
\hline \multicolumn{2}{r|}{ Persentase Aktivitas Siswa (\%) } \\
\hline
\end{tabular}

Berdasarkan tabel diatas terlihat bahwa aktivitas siswa pada Siklus I untuk pertemuan 1 dan pertemuan 2 masih sangat kurang, dimana persentase rata-rata aktivitas siswa adalah $30,90 \%$ pada pertemuan pertama dan $38,18 \%$ pada pertemuan kedua. Secara keseluruhan aspek-aspek pengamatan, skor tertinggi yang diperoleh pada siklus I adalah 3 dan terendah 1.

b. Aktivitas Guru

Berdasarkan hasil observasi selama Kegiatan Belajar Mengajar (KBM) kegiatan guru dalam melaksanakan langkah-langkah RPP pada siklus I adalah sebagai berikut :

Tabel Aktivitas Guru pada Siklus I

\begin{tabular}{|c|c|c|c|}
\hline \multirow{2}{*}{ No } & \multirow{2}{*}{ Aktivitas/Aspek yang Diamati } & \multicolumn{2}{|c|}{ Skor Pengamatan } \\
\hline & & Pert. I & Pert. II \\
\hline \multicolumn{4}{|c|}{ A. Pendahuluan } \\
\hline 1. & Melakukan apersepsi & 2 & 4 \\
\hline 2. & Memberikan motivasi & 2 & 3 \\
\hline 3. & $\begin{array}{l}\text { Menyampaikan tujuan pembelajaran dengan suara } \\
\text { keras dan pandangan guru ditujukan pada seluruh } \\
\text { siswa }\end{array}$ & 2 & 3 \\
\hline 4. & Menjelaskan langkah-langkah PBM & 3 & 5 \\
\hline \multicolumn{4}{|c|}{ B. Kegiatan Inti } \\
\hline 5. & $\begin{array}{l}\text { Mengorganisir siswa kedalam kelompok dan memberi } \\
\text { tugas kepada masing-masing kelompok }\end{array}$ & 2 & 2 \\
\hline 6. & $\begin{array}{l}\text { Mengamati jalannya diskusi (dengan berkeliling, dari } \\
\text { depan dan belakang kelas) }\end{array}$ & 2 & 3 \\
\hline 7. & Menanyakan kesulitan dalam kelompok & 1 & 2 \\
\hline 8. & $\begin{array}{l}\text { Membimbing siswa/kelompok yang bertanya pada } \\
\text { guru }\end{array}$ & 2 & 3 \\
\hline 9. & Menuntun siswa yang melakukan presentasi. & 2 & 2 \\
\hline 10 & $\begin{array}{l}\text { Menuntun siswa yang menanggapi, atau menyanggah } \\
\text { hasil presentasi. }\end{array}$ & 2 & 3 \\
\hline 11 & $\begin{array}{l}\text { Membimbing siswa untuk menyimpulkan hasil } \\
\text { pemecahan masalah melalui diskusi kelas. }\end{array}$ & 2 & 2 \\
\hline 12 & Melakukan pengembangan materi / penguatan & 2 & 4 \\
\hline 13 & $\begin{array}{l}\text { Memberi penghargaan kepada kelompok yang dinilai } \\
\text { berhasil }\end{array}$ & 2 & 2 \\
\hline
\end{tabular}




\begin{tabular}{|c|l|c|c|}
\hline 14 & $\begin{array}{l}\text { Memberi motivasi kepada kelompok yang belum } \\
\text { berhasil }\end{array}$ & 3 & 3 \\
\hline C. Penutup & 3 & 5 \\
\hline 15 & Memberi tugas / PR. & 3 & 3 \\
\hline 16 & Melaksanakan tes / kuis secara individu. & $\mathbf{2 , 1 9}$ & $\mathbf{3 , 0 6}$ \\
\hline \multicolumn{2}{|c|}{ Rata-rata } & $\mathbf{4 3 , 7 5}$ & $\mathbf{6 1 , 2 5}$ \\
\hline \multicolumn{2}{|c|}{ Persentase Aktivitas Guru ( \% ) }
\end{tabular}

Aktivitas guru siklus I baik pada pertemuan pertama maupun pada pertemuan kedua masih kurang seperti terlihat dalam tabel diatas, dimana persentase rata-rata aktivitas guru pada pertemuan pertama adalah $43,75 \%$ dan $61,25 \%$ pada pertemuan kedua. Namun pada pertemuan kedua akvitas guru meningkat sebesar 17,50 \% terhadap aktivitas pertemuan pertama. Nilai atau skor aktivitas tertinggi diperoleh pada Siklus I ini adalah 5 dan terendah adalah 1.

c. Hasil Belajar Siswa

Hasil belajar siswa dapat dilihat pada tabel berikut:

Tabel Hasil Belajar Siswa Siklus I

\begin{tabular}{|c|c|c|c|}
\hline \multirow{2}{*}{ No } & \multirow{2}{*}{ Ketuntasan } & \multicolumn{2}{|c|}{ KKM $\mathbf{7 5}$} \\
\cline { 3 - 4 } & & Jumlah & Persentase (\%) \\
\hline 1. & Tuntas & 15 & 65,2 \\
\hline 2. & Tidak Tuntas & 8 & 34,8 \\
\hline \multicolumn{2}{|c|}{ Jumlah Siswa } & \multicolumn{2}{|c|}{$\mathbf{2 3}$} \\
\hline & Rata-Rata Kelas & \multicolumn{2}{|c|}{} \\
\hline
\end{tabular}

Berdasarkan penelitian hasil akhir belajar siswa atau ketuntasan pada siklus I adalah 15 siswa $(65,2 \%)$ dari 23 siswa keseluruhannya dinyatakan tuntas dan 8 siswa $(34,8 \%)$ dinyatakan tidak tuntas, dengan perolehan nilai rata-rata kelas sebesar 74,1 (terlampir), seperti terlihat dalam tabel di atas. Nilai tertinggi diperoleh sebesar 90 dan terendah 55.

\section{Refleksi.}

Berdasarkan hasil pengamatan, keberhasilan yang telah dicapai pada siklus I adalah sebagai berikut:

a. Nilai rata-rata yang diperoleh siswa pada siklus I adalah 74,1 dan siswa yang memperoleh kategori tuntas sebanyak 15 siswa $(65,2 \%)$ dari total 23 siswa. Secara klasikal belum mencapai ketuntasan belajar siswa yaitu $\geq 85 \%$ yang memperoleh nilai $\geq 75$.

b. Aktivitas siswa pada pertemuan pertama masih banyak yang kurang dengan persentase sebesar 30,90\%, pada pertemuan kedua aktivitas siswa meningkat 7,28\% menjadi 38,18\% dengan kriteria cukup.

c. Aktivitas guru memperoleh persentase sebesar $43,75 \%$ pada pertemuan pertama dengan masih banyak yang termasuk kategori atau kriteria cukup, akan tetapi sebagian kecil aspek pengamatan memperoleh kriteria baik. Aktivitas guru meningkat pada pertemuan kedua menjadi baik dengan persentase sebesar $61,25 \%$.

Berdasarkan hasil refleksi maka upaya yang harus dilakukan atau hal-hal yang harus diperbaiki dan ditingkatkan dari siklus I antara lain :

a. Nilai hasil belajar siswa perlu ditingkatkan lagi

b. Aktivitas siswa masih banyak yang kurang dan perlu kiranya ditingkatkan terutama dalam hal berpartisipasi dalam kelompok, kemauan mempresentasikan hasil diskusi, kemauan memberi tanggapan hasil presentasi temannya, dan juga dalam bekerjasama dalam kelompoknya. 
c. Perlu kiranya ditingkatkan lagi aktifitas guru baik dalam mengelola kelas maupun melaksanakan langkah-langkah pembelajaran terutama pada membimbing siswa yang kesulitan dalam kelompoknya, membimbing siswa untuk tampil mempresentasikan hasil diskusinya, memotivasi siswa untuk berani bertanya dan juga memotivasi siswa untuk bekerjasama dan berpartisipasi dalam kelompok.

\section{Deskripsi Hasil Siklus II}

\section{Perencanaan}

Perencanaan (planning) terdiri atas kegiatan :

a. Menyusun Rencana Pelaksanaan Pembelajaran

Materi yang dipilih dalam penelitian ini adalah materi siklus akuntansi perusahaan jasa. Berdasarkan materi yang dipilih tersebut, kemudian disusun ke dalam rencana pelaksanaan pembelajaran (RPP). Masing-masing RPP diberikan alokasi waktu sebanyak 2 x 45 menit, artinya setiap RPP disampaikan dalam 1 kali tatap muka. Pada siklus I terjadi dua kali pertemuan atau dua kali tatap muka (terlampir).

b. Penyiapan skenario pembelajaran

1) Mempersiapkan beberapa hal yang diperlukan dalam pelaksanaan penelitian yaitu: membuat RPP, menyusun instrumen PBM guru peneliti dan menyusun instrumen respon siswa terhadap kegiatan pembelajaran.

2) Mempersiapkan kelompok belajar siswa dengan memperhatikan heterogenitas, kemampuan dan jenis kelamin.

\section{Pelaksanaan}

a. Kegiatan belajar mengajar dilaksanakan pada hari selasa tanggal 22 September 2020 dan hari sabtu tanggal 26 September 2020.

b. Secara klasikal menjelaskan strategi dalam menggunakan model problem base learning.

c. Melaksanakan proses pembelajaran dengan pembelajaran model problem base learning.

d. Siswa dibagi ke dalam 6 (enam) kelompok. Guru memberikan permasalahan tentang materi siklus akuntansi perusahaan jasa yang berbeda kepada masingmasing kelompok.

e. Kelompok I, II dan III ditugaskan untuk melakukan analisis transaksi ke dalam jurnal.

f. Kelompok IV, V, dan VI ditugaskan untuk memposting jurnal ke dalam buku besar.

g. Guru meminta siswa untuk mendiskusikan materi yang telah diberikan.

h. Selama siswa bekerja di dalam kelompok, guru memperhatikan dan mendorong semua siswa untuk terlibat diskusi dan membimbing siswa.

i. Dua kelompok diskusi diminta untuk mempresentasikan hasil diskusinya ke depan kelas. Sementara kelompok lain, menanggapi dan menyempurnakan apa yang dipresentasikan.

j. Guru mengumpulkan semua hasil diskusi tiap kelompok

k. Guru menutup pembelajaran ini dengan memberikan ringkasan tentang jurnal dan buku besar dan mengajak berdoa semoga pembelajaran hari ini bermanfaat untuk kita semua.

1. Pengamatan terhadap proses kegiatan ini dicatat secara cermat dan didokumentasikan sebagai bagian dari kegiatan pengamatan.

m. Akhir dari kegiatan PBM dilakukan tes tertulis. 
n. Penilaian hasil tes tertulis.

\section{Observasi}

Observasi dilakukan terhadap aktifitas belajar siswa dan PBM pada siklus II yang telah dirubah tata cara penyusunannya, satu hal yang menjadikan PBM pada siklus II menjadi lebih menarik dan menyenangkan adalah pembelajaran langsung ke materi siklus akuntansi perusahaan jasa.

Observasi yang dilakukan pada siklus I ini antara lain adalah aktivitas siswa saat PBM berlangsung dan Pelaksanaan PBM yang diselenggarakan oleh guru.

a. Aktivitas Siswa

Aktivitas siswa siklus II pada pertemuan ketiga dan keempat dapat digambarkan dalam tabel berikut ini.

Tabel Aktivitas Siswa Siklus II

\begin{tabular}{|c|l|c|c|}
\hline No & \multicolumn{1}{|c|}{ Aspek Pengamatan } & Skor Pengamatan \\
\cline { 3 - 4 } & \multicolumn{1}{|c|}{ Pert.III } & Pert. IV \\
\hline 1. & Memperhatikan penjelasan guru & 3 & 4 \\
\hline 2. & Keaktifan dalam bertanya tentang materi & 2 & 5 \\
\hline 3. & $\begin{array}{l}\text { Siswa dapat mengkondisikan dirinya dalam kelompok } \\
\text { yang telah dibentuk }\end{array}$ & 3 & 3 \\
\hline 4. & $\begin{array}{l}\text { Antusias siswa dalam mengikuti kegiatan belajar } \\
\text { mengajar }\end{array}$ & 2 & 5 \\
\hline 5. & Keberanian untuk bertanya pada teman & 3 & 5 \\
\hline 6. & $\begin{array}{l}\text { Kemauan untuk saling membantu/bekerjasama dalam } \\
\text { kelompok }\end{array}$ & 2 & 3 \\
\hline 7. & Partisipasi setiap siswa dalam diskusi kelompok & 3 & 4 \\
\hline 8. & Kemauan mempresentasikan hasil diskusi kelompok & 2 & 3 \\
\hline 9. & $\begin{array}{l}\text { Kemauan memberikan tanggapan, bertanya atau } \\
\text { menyanggah yang dipresentasikan }\end{array}$ & 2 & 4 \\
\hline 10 & Menyimpulkan hasil diskusi & 3 & 4 \\
\hline 11. & $\begin{array}{l}\text { Respon terhadap penghargaan yang diberikan guru } \\
\text { kepada kelompok }\end{array}$ & 3 & 5 \\
\hline \multicolumn{2}{|c|}{ Rata-rata } & $\mathbf{2 , 5 4}$ & $\mathbf{4 , 0 9}$ \\
\hline & Persentase Aktivitas Siswa ( \% ) & $\mathbf{8 1 , 8}$ \\
\hline
\end{tabular}

Berdasarkan tabel diatas, aktivitas siswa pada siklus II meningkat bila dibandingkan dengan siklus I. Pada pertemuan keempat siklus II persentase aktivitas siswa sebesar $81,8 \%$ dengan skor tertinggi adalah 5 yang diperoleh siswa untuk beberapa aspek pengamatan dan terendah 3. Persentase aktivitas siswa pada pertemuan ketiga siklus II sebesar $50.8 \%$ siswa yang aktif.

b. Aktivitas Guru

Berdasarkan hasil observasi selama Kegiatan Belajar Mengajar (KBM) kegiatan guru dalam melaksanakan langkah-langkah RPP pada siklus II adalah sebagai berikut :

Tabel Aktivitas Guru pada Siklus II

\begin{tabular}{|l|l|c|c|}
\hline \multirow{2}{*}{ No } & \multicolumn{1}{|c|}{ Aktivitas/Aspek yang Diamati } & \multicolumn{2}{c|}{ Skor Pengamatan } \\
\cline { 3 - 4 } & \multicolumn{2}{|c|}{ Pert. III } & Pert. IV \\
\hline A. Pendahuluan & 3 & 5 \\
\hline 1. & Melakukan apersepsi & 3 & 4 \\
\hline 2. & Memberikan motivasi & 3 & 3 \\
\hline 3. & Menyampaikan tujuan pembelajaran dengan suara &
\end{tabular}




\begin{tabular}{|c|c|c|c|}
\hline & $\begin{array}{l}\text { keras dan pandangan guru ditujukan pada seluruh } \\
\text { siswa }\end{array}$ & & \\
\hline 4. & Menjelaskan langkah-langkah PBM & 4 & 5 \\
\hline \multicolumn{4}{|c|}{ B. Kegiatan Inti } \\
\hline 5. & $\begin{array}{l}\text { Mengorganisir siswa kedalam kelompok dan memberi } \\
\text { tugas kepada masing-masing kelompok }\end{array}$ & 3 & 4 \\
\hline 6. & $\begin{array}{l}\text { Mengamati jalannya diskusi (dengan berkeliling, dari } \\
\text { depan dan belakang kelas) }\end{array}$ & 3 & 5 \\
\hline 7. & Menanyakan kesulitan dalam kelompok & 2 & 3 \\
\hline 8. & $\begin{array}{l}\text { Membimbing siswa/kelompok yang bertanya pada } \\
\text { guru }\end{array}$ & 3 & 5 \\
\hline 9. & Menuntun siswa yang melakukan presentasi. & 4 & 4 \\
\hline 10 & $\begin{array}{l}\text { Menuntun siswa yang menanggapi, atau menyanggah } \\
\text { hasil presentasi. }\end{array}$ & 3 & 4 \\
\hline
\end{tabular}

\begin{tabular}{|c|l|c|c|}
\hline 11 & $\begin{array}{l}\text { Membimbing siswa untuk menyimpulkan hasil } \\
\text { pemecahan masalah melalui diskusi kelas. }\end{array}$ & 2 & 2 \\
\hline 12 & Melakukan pengembangan materi / penguatan & 5 & 5 \\
\hline 13 & $\begin{array}{l}\text { Memberi penghargaan kepada kelompok yang dinilai } \\
\text { berhasil }\end{array}$ & 3 & 3 \\
\hline 14 & $\begin{array}{l}\text { Memberi motivasi kepada kelompok yang belum } \\
\text { berhasil }\end{array}$ & 3 & 5 \\
\hline C. Penutup & 3 & 5 \\
\hline 15 & Memberi tugas / PR. & 3 & 3 \\
\hline 16 & Melaksanakan tes / kuis secara individu. & $\mathbf{3 , 1 3}$ & $\mathbf{4 , 0 6}$ \\
\hline \multicolumn{2}{|c|}{ Rata-rata } & $\mathbf{6 2 , 6}$ & $\mathbf{8 1 , 2}$ \\
\hline
\end{tabular}

Aktivitas Guru pada siklus II untuk semua aspek pengamatan secara keseluruhan meningkat bila dibandingkan dengan aktivitas guru pada siklus I. Skor rata-rata yang diperoleh adalah 3 pada pertemuan ketiga dan 4 pada pertemuan keempat, dengan persentase aktivitas sebesar $81,2 \%$ pada pertemuan keempat dan $62,6 \%$ pada pertemua ketiga.

c. Hasil Belajar Siswa

Hasil belajar siswa dapat dilihat pada tabel berikut:

Tabel Hasil Belajar Siswa Siklus II

\begin{tabular}{|c|c|c|c|}
\hline \multirow{2}{*}{ No } & \multirow{2}{*}{ Ketuntasan } & \multicolumn{2}{|c|}{ KKM $\mathbf{7 5}$} \\
\cline { 3 - 4 } & & Jumlah & Persentase (\%) \\
\hline 1. & Tuntas & 21 & 91,3 \\
\hline 2. & Tidak Tuntas & 2 & 8,7 \\
\hline \multicolumn{2}{|c|}{ Jumlah Siswa } & \multicolumn{2}{|c|}{$\mathbf{2 3}, \mathbf{8 2 , 6}$} \\
\hline \multicolumn{2}{|c|}{ Rata-Rata Kelas } & \multicolumn{3}{|c|}{} \\
\hline
\end{tabular}

Berdasarkan penelitian hasil akhir belajar siswa atau ketuntasan pada siklus II adalah 21 siswa $(91,3 \%)$ dari 23 siswa keseluruhannya dinyatakan tuntas dan 2 siswa $(8,7 \%)$ dinyatakan tidak tuntas, dengan perolehan nilai rata-rata kelas sebesar 82,6 (terlampir), seperti terlihat dalam tabel 4.6 di atas. Nilai tertinggi diperoleh sebesar 100 dan terendah 60 . 


\section{Refleksi.}

Berdasarkan hasil pengamatan, keberhasilan dan ketuntasan yang telah dicapai pada siklus II adalah sebagai berikut:

a. Nilai rata-rata yang telah diperoleh pada siklus II adalah 82,6 dan siswa yang tuntas sebanyak $21(91,3 \%)$ siswa dari total 23 siswa. Secara klasikal hasil belajar mengajar pada akhir siklus II ini telah mencapai ketuntasan belajar siswa, yaitu jumlah siswa yang tuntas adalah $\geq 85 \%$ dengan perolehan nilai $\geq 75$.

b. Aktivitas siswa pada pertemuan ketiga termasuk katagori cukup dengan persentase sebesar 50,8 \%, pada pertemuan ke empat aktivitas siswa meningkat menjadi sangat baik dengan persentase $81,8 \%$.

c. Aktivitas guru memperoleh persentase sebesar $62,6 \%$ pada pertemuan ketiga termasuk dalam kategori baik, pada pertemuan keempat meningkat menjadi sangat baik dengan persentase sebesar $81,2 \%$.

\section{Pembahasan}

\section{Hasil belajar siswa}

Berdasarkan hasil pengamatan pada siklus I dan siklus II mengalami peningkatan hasil belajar dan juga aktivitas baik bagi guru maupun bagi siswa dalam kegiatan belajar mengajar dan mencapai ketuntasan. Hasil tes pada siklus I dengan persentase ketuntasan sebesar $65,2 \%$, nilai rata-rata kelas sebesar 74,1 dan hasil tes siklus II sebesar 91,3\% dengan nilai rata-rata kelas 82,6. Maka terlihat bahwa nilai siswa telah mencapai standar ketuntasan secara klasikal pada siklus II yaitu $\geq 85 \%$. Mulyana (2005:99) menyatakan. "keberhasilan kelas dilihat dari jumlah peserta didik yang mampu menyelesaikan atau mencapai sekurang-kurangnya $85 \%$ dari jumlah peserta didik yang ada di kelas tersebut. Dengan demikian dapat disimpulkan terdapat peningkatan hasil belajar siswa selama dua siklus dan telah tuntas secara klasikal pada materi siklus akuntansi perusahaan jasa dengan menggunakan model problem base learning. Hal ini disebabkan adanya peningkatan interaksi yang terjadi sehingga mengakibatkan efek yang positif terhadap pemahaman siswa dalam mempelajari materi ajar. Hasil tes pada siklus I dan II berbeda dengan hasil tes pra siklus dengan perolehan nilai rata-rata kelas adalah 64,6 dan ketuntasan siswa yang dicapai hanya 43,5\%.

Tabel Hasil Belajar Siswa Gabungan

\begin{tabular}{|c|c|c|c|c|c|c|c|}
\hline \multirow{2}{*}{ No } & \multirow{2}{*}{ Ketuntasan } & \multicolumn{2}{|c|}{ Pra Siklus } & \multicolumn{2}{|c|}{ Siklus I } & \multicolumn{2}{|c|}{ Siklus II } \\
\hline & & Jumlah & $\%$ & Jumlah & $\%$ & Jumlah & $\%$ \\
\hline 1. & Tuntas & 12 & 43,5 & 19 & 65,2 & 26 & 91,3 \\
\hline 2. & Tidak Tuntas & 17 & 56,5 & 10 & 34,8 & 3 & 8,7 \\
\hline \multicolumn{2}{|c|}{ Jumlah Siswa } & \multicolumn{2}{|c|}{23} & \multicolumn{2}{|c|}{23} & \multicolumn{2}{|c|}{23} \\
\hline \multicolumn{2}{|c|}{ Rata-Rata Kelas } & \multicolumn{2}{|c|}{64,6} & \multicolumn{2}{|c|}{74,1} & \multicolumn{2}{|c|}{82,6} \\
\hline
\end{tabular}

Keterangan : Nilai KKM 75

\section{Proses Pembelajaran}

Aktivitas siswa pada siklus I masih termasuk kategori cukup dengan persentase sebesar $38.18 \%$ dan aktivitas guru dalam proses pembelajaran siklus I sudah cukup baik dalam hal menyampaikan materi, mengorganisir sisiwa dan mengelola kelas dengan persentase $61,25 \%$. Pada siklus II aktivitas siswa semakin meningkat dengan kategori sangat baik dalam hal bertanya, tampil ke depan kelas, bekerjasama, mengkondisikan diri dalam kelompok, dan juga memberi tanggapan terhadap hasil presentasi temannya dengan persentase sebesar $81,8 \%$. Hal ini dikarenakan siswa sudah 
terbiasa dengan penggunaan model problem base learning dan juga siswa sudah bisa berkerjasama dan berpartisipasi yang baik dalam kelompoknya.

Untuk lebih jelasnya perkembangan nilai siswa pada masing-masing siklus dan pertemuan dapat dilihat pada diagram berikut ini :

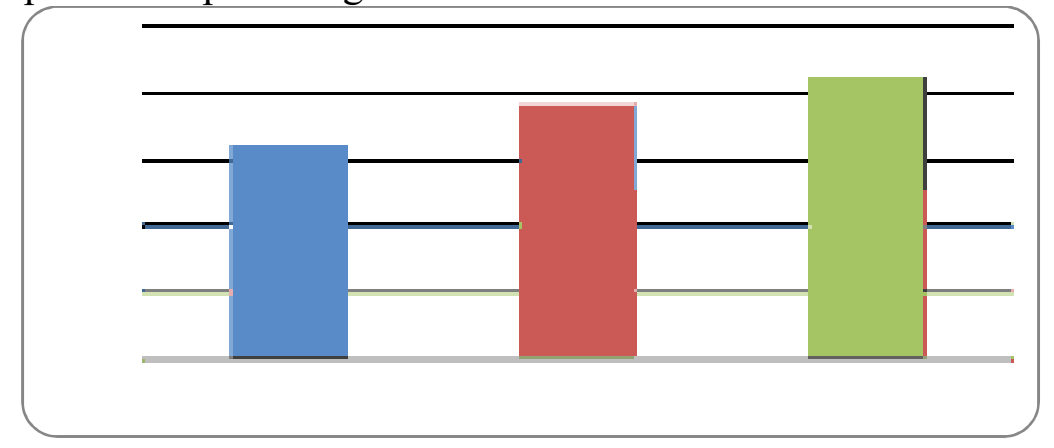

Gambar Daftar Nilai Siswa

\section{Kesimpulan}

Berdasarkan hasil penelitian ini dapat disimpulkan bahwa dengan menerapkan model problem base learning dapat meningkatkan hasil belajar ekonomi materi siklus akuntansi perusahaan jasa pada siswa kelas XII-IPS SMA Kartika XIV-1 Banda Aceh. Peningkatan hasil belajar siswa tersebut terlihat dalam hal meningkatnya nilai rata-rata, persentase ketuntasan siswa dan juga suasana belajar siswa yang berbeda dari suasana belajar sebelum dilakukan tindakan. Hasil perolehan pada siklus I dengan persentase ketuntasan sebesar $65,2 \%$ nilai rata-rata kelas sebesar 74,1 dan meningkat pada hasil tes siklus II sebesar $89,7 \%$ dengan nilai rata-rata kelas 82,6 . Pada kedua siklus ini terjadi perubahan aktifitas dan perolehan nilai yang signifikan bila dibandingkan dsengan pra siklus dengan ketuntasan belajar yang hanya mencapai 43,5\% siswa dan nilai rata-rata kelas 64,6. Adapun hasil pengamatan pada proses belajar mengajar menunjukkan aktivitas siswa lebih meningkat selama proses pembelajaran berlangsung, baik pada siklus I maupun pada siklus II dibandingkan dengan suasana belajar siswa yang pasif dan kaku sebelum dilakukannya tindakan kelas. Perolehan persentase keaktifan siswa pada siklus I adalah 38,18\% dan pada siklus II adalah 61,25\%. Aktivitas guru juga meningkat pada siklus I dan siklus II dalam hal penggunaan metode dengan perolehan persentase skor adalah 43,75\% dengan kategori cukup menjadi $81,8 \%$ pada siklus II dengan kategori baik.

\section{DAFTAR PUSTAKA}

Anas Sudijono. 2005. Pengantar Evaluasi Pendidikan. Jakarta : PT. Raja Grafindo Persada.

Aqib, Zainal, 2009. Penelitian Tindakan Kelas untuk Guru. Bandung: Yrama Widya Daryanto, 2009. Panduan Proses Pembelajaran Kreatif \& Inovatif. Jakarta: Publisher. Hamalik, Oemar. 2001. Proses Belajar Mengajar. Jakarta : Bumi Aksara.

Hamalik, Oemar. 2008. Kurikulum dan Pembelajaran. Jakarta : Bumi Aksara.

Slameto. 2003 . Belajar dan Faktor-faktor yang Mempengaruhinya. Bandung: PT. Rineka Cipta.

Sumadi. 2002. Prestasi dalam Belajar. Jakarta : Pustaka Widyamara.

Wina Sanjaya. 2008. Belajar dan Faktor-Faktor Yang Mempengaruhinya. Rineka Cipta; Jakarta.

Winkel, WS 1997. Psikologi Pendidikan dan Evaluasi Belajar. Jakarta : Gramedia. 